\title{
The Influence of Methods For Fractination of Free Fatty Acid Fraction From Coconut Milk Hydrolysis Using Coconut Lipase Endogeneus Enzyme
}

\author{
$1^{\text {st }}$ Moh. Su' ${ }^{1}, 2^{\text {nd }}$ Enny Sumaryati ${ }^{1}, 3^{\text {rd }}$ Yudi Utomo $^{2}, 4^{\text {th }}$ Panca Eric $^{1}$ \\ \{sui_uwg@yahoo.co.id ${ }^{1}$ \} \\ Faculty of Agriculture, Widyagama University of Malang, J1. Borobudur No. 25, Malang, \\ Indonesia $^{1}$, Department of Chemistry at State University of Malang, Jl. Semarang No. 5, \\ Malang, Indonesia ${ }^{2}$
}

\begin{abstract}
The coconut milk that is hydrolyzed will get the oil fraction in the form of free fatty acids, monoglycerides and diglycerides. Free fatty acids in the form of lauric acid and monoglycerides in the form of monolaurin have very high antibacterial and antiviral abilities. This research aims to study the method of fractionation of oil fractions resulting from hydrolysis of coconut milk using the enzyme lipase. The study was conducted by hydrolyzing coconut milk using endogenous lipase enzyme. Hydrolisates are separated by oil fractions by several methods, namely heating, fishing, papain enzyme and salting. The separation fraction of oil was measured for yield, free fatty acid levels. Furthermore, the separation of free fatty acids from oil and hydrolyzed coconut. The free fatty acid fraction obtained was tested for yield and fatty acid composition. The results showed that, the method of separation with fishing oil yielded the highest yield of $47 \%$. Then followed by salting method and papain enzyme method respectively $40 \%$ and $39 \%$. The lowest yield obtained by heating method is 28.69. But the enzyme papain method produces the highest levels of free fatty acids, which is $0.07 \mathrm{ml} \mathrm{mol} / \mathrm{ml}$. While the method of fishing and salting oil has the lowest free fatty acid level, which is $0.04 \mathrm{ml}$ mol $/ \mathrm{ml}$. The results of the most free fatty acid separation were obtained from hydrolyzed coconut milk at $5.32 \%$. Whereas free fatty acids obtained from the oil fraction were $4.52 \%$.
\end{abstract}

Keywords: Lipase; coconut milk; hydrolysis; fractination

\section{Introduction}

Coconut milk is one of the processed products from coconut meat which can be processed into coconut oil. Coconut milk is a naturally formed emulsion. In coconut milk there is coconut oil, water and emulsifier. According to [1], coconut oil contains lauric acid $52.26 \%$, myristic acid $16.82 \%$, caprilic acid $8.21 \%$, capric acid $7.79 \%$, caproic acid $0.24 \%$, palmitic acid $6,59 \%$, stearic acid $1.51 \%$, oleic acid $4.83 \%$ and linoleic acid $1.33 \%$.

Coconut oil contains many medium chain fatty acids (MCFA) such as capric acid and myristic acid, which is very useful as an anti-bacterial agent [2], anti-microbial [3], can inhibit the development of the HIV virus [4], herpes virus, influenza and sarcoma [5]. In addition, lauric acid can reduce blood cholesterol levels [6]. 
These fatty acids can inhibit the growth of Pneumococci, Streptococcus, Micrococci, Candida, S. aureus, S. epidermis. Lauric acid only requires a concentration of 0.062 micro mol $/ \mathrm{ml}$ which can inhibit pneumococci. Whereas capric acid and myristic acid each need 1.45 micro $\mathrm{mol} / \mathrm{ml}$ and $0.218 \mathrm{micro} \mathrm{mol} / \mathrm{ml}$ to inhibit the same microbes [3].

These fatty acids have anti-bacterial ability if in the form of free fatty acids and monoglycerides. Fatty acids in the form of diglycerides and triglycerides, do not have antibacterial activity.

Lauric acid in the form of free fatty acids requires a concentration of 0.62 micromol $/ \mathrm{ml}$ to inhibit Micrococci bacteria. Whereas in the form of monolaurin (monoglyceride) only requires $0.09 \mathrm{micromol} / \mathrm{ml}[3]$.

Lauric acid in the form of dilaurine and tri laurin cannot inhibit Micrococci growth to a concentration of 6 micromol / ml. While capric acid requires $2.90 \mathrm{micromol} / \mathrm{ml}$ and in the form of mono caprin requires $0.10 \mathrm{micromol} / \mathrm{ml}$. Whereas in the form of capaprin it is not able to inhibit Micrococci [3].

Hydrolysis of oil into free fatty acids can be done using the lipase enzyme. Lipase in plant seeds plays a role in hydrolyzing oils (triglycerides), diglycerides and mono glycerides into free fatty acids (lauric acid, etc.) and glycerol [7]. The lipase enzyme is able to hydrolyze ester bonds from oil (glycerides) to produce free fatty acids [8].

Lipase enzymes from other source, namely coconut houstorium, can hydrolyze coconut oil into free fatty acids. Hydrolization produces $40.20 \%$ of the total fatty acids in coconut oil [9].

Further research on lipase enzyme isolation from coconut milk has been carried out by [10]. The results showed that coconut milk contained lipase enzyme of 3.15 units $/ \mathrm{ml}$ and specific activity was 1.41 units / $\mathrm{mg}$ of protein.

The free fatty acid fraction was obtained from hydrolysis of coconut milk made by adding 1: 1 water to grated coconut then squeezed. Hydrolysis was carried out for 72 hours. Endogenous enzymes in coconut milk will hydrolyze coconut oil into free fatty acids during incubation. After separation, the free fatty acid fraction obtained was $48.98 \%$ of the total coconut oil in coconut milk. The free fatty acid fraction contained lauric acid $53.86 \%$, myristic acid $16.71 \%$, caprylate acid $7.86 \%$, capric acid $7.76 \%$ and palmitic acid $6.60 \%$. The fraction is called fraction rich in lauric acid because lauric acid is the highest fatty acid [11].

This fraction can kill pathogenic bacteria such as Salmonella at a concentration of $3.13 \%$, Stafilococus aureus at $6.25 \%$ and E. Coli at $6.25 \%$. whereas in spoilage bacteria, the free fatty acid fraction can kill Micrococus at 30\% concentration, Bacillus stearothermophillus at 50\% concentration and Pseudomonas with a concentration of 70\% [12].

The addition of fractions rich in lauric acid into soy milk with a concentration of $20 \%$ can increase the storage of soy milk up to 2 days with a total microbes of $1.00 \times 104 \mathrm{cfu} / \mathrm{ml}$, free fatty acids $0.12 \mathrm{~m} \mathrm{~mol} / \mathrm{ml}, \mathrm{pH} 5.05$ and scores aroma 4 (likes). On the 3rd day soy milk has begun to experience damage [13].

This study was conducted to separate the oil fraction resulting from hydrolysis of coconut milk using endogeneous enzymes. The oil fraction obtained is expected to contain high free fatty acids. This is because fatty acids that have anti-bacterial activity are in the form of free fatty acids.

Fractination oil from coconut milk can be done by several methods including (1) chain breaking method (stirring), (2) enzymatic method, (3) salting method, (4) fishing rod method, (5) centrifuse method and (6) freezing method.

Chain breaking method (mixing) is done by stirring coconut milk at high speed using a mixer. During the stirring process there will be a break in the chemical bond on the emulsifier. 
Emulsifiers in coconut milk function to stabilize coconut milk so that coconut oil is not separated from coconut milk. If the chemical bond on the emulsifier breaks, the oil will be separated from the coconut milk [14].

The enzymatic method uses enzymes to damage the coconut milk emulsion. The enzyme used is the protease enzyme, an enzyme that can break down proteins. Some protease enzymes that are easily obtained are papain from papaya or bromelin enzymes from pineapple and zingibain enzyme from ginger rhizome [15].

The fishing oil method is done by adding oil or virgin coconut oil as an angler to the coconut milk (cream). Then it was allowed to stand for 10-12 hours so that the oil from the cream was separated [16].

The salting method was carried out by added $\mathrm{CaCl} 2$ salt into coconut milk and allowed to stand for 12 hours to obtain pure coconut oil [17].

Each method of fractination has its own strengths and weaknesses. There are methods that produce high yield, but low quality. Conversely, there is a method with low yield but good quality. These research aims to obtain oil separation methods that produce high yields and good quality.

\section{Materials and Methods}

This research was conducted from February to December 2017 at the Widya Gama University Chemistry and Biochemistry Laboratory in Malang. Several stages of research were carried out at the Gajah Mada University Biochemistry Laboratory.

The tools used in this study included a set of glassware, plastic filters, stailess steel blades, stainless steel (Brilliant) grate tools, mortars, centrifuges, analytical balance sheets (Mettler Toledo AL 204), stirrer stirrers, heaters (Janke-Kunkel), oven, pH-meter (Orion 201), space thermometer, UV-Vis (Genesys $10 \mathrm{UV}$ series) spectrophotometer, gas chromatography device (model 5890 series HP) with CBPS column.

The ingredients used are, among others, deep varieties of coconut fruit from Lawang Malang Regency, virgin coconut oil (VCO), aquades, ion-free distilled water, $\mathrm{NaCl}$ salt, papain enzyme. Chemicals include arabic gum, ammonium sulfate salt, $\mathrm{NaOH}$, pp indicator, K2HPO4, KH2PO4, Dietyleter, petroleun ether, $\mathrm{NaCO} 3, \mathrm{HCl}$, ethanol.

\subsection{The process of hydrolysis of coconut milk uses endogenous lipase}

The hydrolysis process uses a coconut milk substrate. Coconut milk was made by coconut shelled, then grated. Grated coconut added with distilled water in a ratio of 1: 1, then obtained so that coconut milk was obtained.

Coconut milk was hydrolyzed using endogenous lipase that was already in coconut milk. Hydrolysis was done by incubating coconut milk at $35 \mathrm{oC}$ for 72 hours. During incubation, stirring was carried out using a stirrer at a speed of $150 \mathrm{rpm}$. Products from hydrolysis are called hydrolysates. Hydrolysate was tested for free fatty acids, then fractionated to separate oil and non-oil fractions.

\subsection{Separation of the oil fraction from Hydrolisate}


Fractionation aims to get the oil fraction from hydrolyzate. The resulting hydrolyzate will form 3 fractions namely oil (top), cream (middle) and water (bottom). Cream fraction is an oil-rich fraction. The cream fraction will then be separated (fractionated).

The first stage, fractionation was carried out on the cream fraction using several methods, namely (1) fishing using virgin coconut oil (vco), (2) salting, (3) papain enzyme and (4) heating. Fractionation results were obtained by the oil fraction and the non oil (water) fraction. Each fraction was tested for yield and free fatty acid levels.

\subsection{Separation of free fatty acids}

The fractionation method that produces the highest free fatty acids was the method that uses the enzyme papain. The separation of free fatty acids was carried out using three different samples 1) oil fraction, (2) non-oil fraction and (3). Whole hydrolyzate (still containing oil and non-oil fractions. The yield of free fatty acids from each sample was tested for yield and free fatty acid composition.

Free fatty acid composition test using Gas Chromatography (GC). the average pore sizes of microporous and mesoporous materials, respectively. Thermogravimetric analysis (TGA) was performed using a differential scanning calorimeter/thermogravimetric analyser (MettlerToledo, TGA/DSC 1) from $30^{\circ} \mathrm{C}$ to $800^{\circ} \mathrm{C}$ using $5^{\circ} \mathrm{C}$ min in air atmosphere.

\section{Discussion}

\subsection{Fractions in Hydrolisate}

Coconut milk which has been hydrolyzed for 72 hours at 35 oC (hydrolysate) obtained three fractions, namely oil, cream and water. The results of each fraction of hydrolyzed coconut milk can be seen in Table 1 .

Table 1. The Results of Each Fraction of Hydrolyzed Coconut Milk

\begin{tabular}{|c|c|c|c|c|}
\hline \multirow[b]{2}{*}{ Sample } & \multicolumn{2}{|l|}{ Total $(\mathrm{ml})$} & \multirow[b]{2}{*}{$\begin{array}{l}\mathrm{FFA}(\mathrm{m} \\
\mathrm{mol} / \mathrm{ml})\end{array}$} & \multirow{2}{*}{$\begin{array}{l}\text { Total } \\
\text { FFA (m } \\
\text { mol) in } \\
200 \mathrm{ml} \\
\text { coconut } \\
\text { milk }\end{array}$} \\
\hline & $\begin{array}{l}\text { Before } \\
\text { hydrolysis }\end{array}$ & $\begin{array}{l}\text { After } \\
\text { hydrolysis }\end{array}$ & & \\
\hline Coconut milk & 200 & 0 & 0.20 & 40.50 \\
\hline Oil fraction & 0 & 34.25 & 0.14 & 4.74 \\
\hline Water fraction & 0 & 131.50 & 0.23 & 29.92 \\
\hline Cream fraction & 0 & 30.00 & 0.21 & 6.15 \\
\hline
\end{tabular}

The water fraction is the most fraction among all fractions, followed by the oil fraction and at least the fraction of the cream. The water fraction consists water contained in coconut and water added during coconut milk making. Water added in ratio $1: 1$ on making process coconut milk. Therefore, the amount of water fraction is the most due to the addition of water when making coconut milk. 
Oil fraction is oil in coconut milk which is separated from coconut milk during the hydrolysis process. This oil separation occurs due to the emulsifier damage whose components consist of protein. Emulsifier damage is caused by the activity of protease enzymes in coconut milk which hydrolyze proteins in emulsifiers, causing oil to come out of the coconut emulsion system.

Cream fraction is a fraction that contains oil, emulsifier, protein and some water. Oil that is not released from coconut milk during the hydrolysis process will be in the cream fraction. The next research was to separate oil from the cream fraction.

\subsection{Separation of the Oil Faction from the Cream Fraction}

The separation of oil from the cream fraction used a different (fractionation) separation method between heating methods, salting, papain enzyme and giving coconut oil from the outside to stimulate oil separation (fishing).

This separation is done to determine the efficiency and effectiveness of some of the fractionation methods.

\section{Yield}

The results of the separation are obtained by two factions, namely oil fractions and nonoil (water) fractions. The oil fraction contains hydrolysis products in the form of free fatty acids, mono glycerides and diglycerides. Whereas the water fraction contains many non-oil compounds such as proteins, carbohydrates and other compounds which dissolve in water. The oil fraction produced by several separation methods in different samples can be seen in Table 2.

Table 2. The Amount of Oil Produced by Several Separation Methods on Different Sample Types

\begin{tabular}{|l|c|c|}
\hline Separation Method & Oil Faction (\%) & $\begin{array}{c}\text { Non-Oil Faction } \\
\text { (\%) }\end{array}$ \\
\hline Fishing & 47.26 & 52,74 \\
\hline Salting & 40.02 & 59,98 \\
\hline Papain enzyme & 39.86 & 60,14 \\
\hline Heating & 28.69 & 71,31 \\
\hline
\end{tabular}

Table 2 shows that the separation using heating produces the lowest yield. This is because some of the oil obtained is left behind in blondo (the rest of the oil-making process) thus reducing the amount of oil obtained.

\section{Free Fatty Acid Levels in the Oil Fraction}

The levels of free fatty acids contained in the oil fraction obtained by different separation methods can be seen in Table 3 .

Table 3. Number of Free Fatty Acids in Hydrolyzate With Different Separation Methods

\begin{tabular}{|l|l|}
\hline Separation Method & Free Fatty Acid $(\mathrm{m} \mathrm{mol} / \mathrm{ml})$ \\
\hline Fishing (vco) & 0.04 \\
\hline Salting & 0.04 \\
\hline
\end{tabular}




\begin{tabular}{|l|l|}
\hline Papain enzyme & 0.07 \\
\hline Heating & 0.05 \\
\hline
\end{tabular}

Table 3 shows that the highest levels of free fatty acids were obtained in the fraction resulting from separation by the enzyme papain method. This is because the separation method using papain enzyme was incubated for 24 hours after the addition of papain enzyme. During this incubation, there is still oil hydrolysis by lipase enzymes in cream and coconut milk samples. According to [10], coconut milk contained lipase enzyme of 3.15 units / ml. Endogenous enzymes in coconut milk will hydrolyze coconut oil into free fatty acids during incubation [11].

Whereas in the heating method, incubation is not carried out. Because, heating can denaturated lipase enzyme. According [18], the free fatty acid content of virgin coconut oil processed by heating is lower than that of it which is processed by other methods.

The fishing method is actually incubated. Allegedly, during the incubation, the oil fraction immediately separated from the water fraction because of the addition of oil from outside as an angler. Thus, hydrolysis by the lipase enzyme cannot occur because the lipase enzyme can work if the oil is still an emulsion with water. While the salting method, also does not occur hydrolysis by the enzyme lipase because salt causes protein denaturation including the lipase enzyme found in coconut milk and cream.

\section{Free Fatty Acid Levels in Non Oil (Water) Fractions}

The free fatty acid levels found in the water fraction obtained by different separation methods can be seen in Table 4.

Table 4. The Number of Free Fatty Acids in The Water Fraction With Different Separation Methods

\begin{tabular}{|l|l|}
\hline Separation Method & Free Fatty Acid (m mol/ml) \\
\hline Fishing (vco) & 0.08 \\
\hline Salting & 0.08 \\
\hline Papain enzyme & 0.13 \\
\hline Heating & 0.00 \\
\hline
\end{tabular}

Table 4 shows that the highest levels of free fatty acids in the non-oil fraction (residual fraction) are highest in the papain enzyme method. In the separation by heating method, there is no free fatty acid because in the method there is no residual water fraction. Residues in the form lumps of solid material in coconut milk such as protein, carbohydrates and others. The rest is in the form of solids known as blondo.

The separation method using the papain enzyme produces the highest free fatty acids in the water fraction because the method in the oil fraction also produces the highest free fatty acids. In the papain enzyme method, incubation was carried out for 24 hours after the papain enzyme was added so that the oil hydrolysis by lipase enzyme which caused free fatty acids produced also increased.

The free fatty acids contained in the non-oil fraction are short chain fatty acid compounds such as butyric acid. These fatty acids are free fatty acids which are relatively soluble in water.

\subsection{Free Fatty Acid Separation}

\section{Free Fatty Acids in Each Faction}


Separation of free fatty acids was carried out using the enzyme papain method. This is because this method produces the highest free fatty acids compared to other methods. The results of the separation obtained three fractions namely oil fraction, water fraction (non oil) and cream fraction. Each fraction was tested for free fatty acid levels and hydrolyzed coconut milk before separation. The number of each fraction and free fatty acid levels after separation can be seen in Table 5 .

The highest amount of free fatty acids in coconut milk. This is because coconut milk is a combination of three fractions namely oil, water and cream fractions. After separation, the water fraction contains the most free fatty acids. This may be organic acid and short chain fatty acid (SCFA) in the coconut milk which are contained in the water fraction soluble in water.

Table 5. Free Fatty Acid Levels In Each Section After Separation With The Enzyme Papain Mehod.

\begin{tabular}{|l|l|l|l|l|}
\hline $\begin{array}{l}\text { Before } \\
\text { Separation }\end{array}$ & $\begin{array}{l}\text { After } \\
\text { Separation }\end{array}$ & $\begin{array}{l}\text { Amount } \\
(\mathrm{ml})\end{array}$ & $\begin{array}{l}\mathrm{FFA}(\mathrm{m} \\
\mathrm{mol} / \mathrm{ml})\end{array}$ & $\begin{array}{l}\text { Total } \\
\text { FFA (m } \\
\text { mol) }\end{array}$ \\
\hline Coconut milk & & 200.00 & 0.20 & 40.50 \\
\hline & Oil fraction & 34.25 & 0.14 & 4.74 \\
\hline & $\begin{array}{l}\text { Water } \\
\text { fraction }\end{array}$ & 131.50 & 0.23 & 29.92 \\
\hline & $\begin{array}{l}\text { Cream } \\
\text { fraction }\end{array}$ & 30.00 & 0.21 & 6.15 \\
\hline
\end{tabular}

\section{Results of Free Fatty Acid Separation in Each Section}

At this stage, the separation of free fatty acids is carried out in three ways: using different ingredients (1) a mixture of all fractions (hydrolyzed coconut milk), (2) oil fraction and (3) water or residual fraction. The number of free fatty acids from each fraction can be seen in Table 6.

Table 6. The Number of Free Fatty Acids in Each Fraction

\begin{tabular}{|l|c|c|c|}
\hline Sample & \multirow{2}{*}{$\begin{array}{c}\text { Amount } \\
(\mathrm{ml})\end{array}$} & \multicolumn{2}{|c|}{ Free fatty acid fraction } \\
\cline { 3 - 4 } & & Volume $(\mathrm{ml})$ & $(\%)$ \\
\hline $\begin{array}{l}\text { Hydrolyzed coconut } \\
\text { milk }\end{array}$ & 200 & 9,27 & 5.32 \\
\hline Oil Fraction & 33.15 & 1,40 & 4.52 \\
\hline Water Fraction & 129.5 & 0,03 & 0.23 \\
\hline
\end{tabular}

After through the fractionation process, the highest free fatty acids were obtained from hydrolyzed coconut milk as much as $9.27 \mathrm{ml}$ in $200 \mathrm{ml}$ coconut milk. Then followed by the oil fraction and the lowest water fraction. This is because free fatty acids in coconut milk are a combination of free fatty acids in the oil fraction and water fraction.

The water fraction contains the lowest free fatty acids. When compared to the results of free fatty acid testing (Table 5), the water fraction contains the most free fatty acids. This is because free fatty acids measured in Table 4 are a mixture of free fatty acids and organic acids present in coconut meat. When fractionating with organic solvents, these organic acids cannot 
be separated because they cannot dissolve in organic solvents. So that only free fatty acids derived from coconut oil are obtained.

\section{Free Fatty Acid Composition in Each Faction}

Free fatty acids obtained from fractionation were tested for fatty acid composition using gas chromatography (GC). The composition of fatty acids from coconut milk, oil fraction and water fraction can be seen in Table 7. Chromatogram of free fatty acids from coconut milk, oil fraction and water fraction can be seen in Figure 1,2 and 3.

Table 7. Composition of Free Fatty Acids In Each Part After Separation With The Enzyme Papain Method

\begin{tabular}{|l|l|l|l|}
\hline $\begin{array}{l}\text { Types of Fatty } \\
\text { Acids }\end{array}$ & $\begin{array}{l}\text { Hydrolyzed } \\
\text { Coconut Milk } \\
(\%)\end{array}$ & $\begin{array}{l}\text { Oil Faction } \\
(\%)\end{array}$ & $\begin{array}{l}\text { Water } \\
\text { Faction (\%) }\end{array}$ \\
\hline Caproic Acid & 2.4290 & 0.4441 & 9.9847 \\
\hline Caprilic Acid & 15.4224 & 12.6556 & 17.4949 \\
\hline Capric Acid & 8.4623 & 8.4777 & 7.3451 \\
\hline Lauric Acid & 40.6499 & 40.2471 & 35.4205 \\
\hline Miristic Acid & 15.8958 & 17.1438 & 12.8041 \\
\hline Palmitic Acid & 6.2366 & 6.8868 & 5.0365 \\
\hline Linoleic Acid & 0.2097 & 0.1468 & 0.3370 \\
\hline Oleic Acid & 5.7104 & 5.6310 & 4.6364 \\
\hline Stearic Acid & 1.6226 & 1.8123 & 1.5155 \\
\hline
\end{tabular}

The composition of free fatty acids from coconut milk and oil fraction is not much significant difference. But in the water fraction, the composition of free fatty acids is somewhat different. The difference is seen in caproic acid and caprylate which is higher than the coconut fraction and oil fraction. Caproic acid and caprylate acid have shorter carbon chains than other fatty acids. This fatty acid is more soluble in water than fatty acids with long carbon atoms. This shows that free fatty acids in many water fractions contain free fatty acids which are easily soluble in water.

\section{Conclusions and Recommendations}

\subsection{Conclusions}

The highest levels of free fatty acids were $0,13 \mathrm{~m} \mathrm{~mol} / \mathrm{ml}$ obtained by papain enzyme fractination methode. The highest amount of free fatty acid fraction was obtained from hydrolyzed coconut milk, followed by oil fraction and the lowest water fraction.

\subsection{Recommendations}

Further research is needed on the separation of monoglysedes and diglyserides from hydrolyzed coconut milk. 
Acknowledgements. This paper in conjuction with the 9th International Conference On Green Technology (ICGT) 2018.

\section{References}

[1] Su'i, M., (2009), Lipase from Coconut and Its Application to Hidrolysis Coconut Oil, Disertations of Doctorate Program, Brawijaya University, Malang

[2] Vetter S.M. and Schlievert, (2005), Gliserol monolaurate inhibits virulence factor production in Bacillus anthracis, Antimicrob Agent Chemother, April 49 (4): 1302-1305.

[3] Kabara J.J., Swieczkowski D.M., Conley A.J. and Truant J.P., (1972), Fatty acid derivatives as antimicrobial agent, Antimicrobial Agent and Chemotherapy, 2(1): 23-28.

[4] Conrado S. D., (2002), Coconaut Oil in Health and Disease : Its and Monolaurin'S Potential as Cure for HIV/Aids, Cocotech Meeting XXXVII th , Chennai, India, July 25, 2002.

[5] Preuss H.G., (2001), Lipid coated viruses (LCVs) and bacteri (LCBs), Copy right 2001, http://www. lauric.org. [5 Juli 2005].

[6] Nicole M. R., Evert G.S. and Martijn B.K., (2001), Consumption of a Solid Fat Rich in Lauric Acid Result in a More Favorable Serum Lipid Profile in Healthy Men and Women the Consumption of a Solid Fat Rich in Trans-Fatty Acid, Journal of Nutrition, 131 : 242-245.

[7] Pahoja VM, Dahot MU and Sethar MA, 2001, Characteristic Properties of Lipase Crude Extract of Caesalpinia bounducella L. Seeds, J. of Biological Sciences, 1 (8): 775-778.

[8] Sana, Hossin I., Haque E.M. and Shaha R.K., 2004, Identification, Purification and Characterization of Lipase from Germination Oil Seed, Pakistan Journal of Biological Sciences, 7 (2): $246-252$.

[9] Su'i, Harijono, Yunianta and Aulani'am, 2010, Lipase Enzyme Hydrolysis Activity From Coconut Kentos Against Coconut Oil, Agritech Journal of Agricultural Technology Gajah Mada University Yogyakarta, 2 (2) : $164-167$

[10] Su'i, M. and Suprihana, 2013, Fractionation of Lipase Enzymes from Endosperm Coconut with the Salting Out Method, Agritech Journal of Agricultural Technology, Gajah Mada University Yogyakarta, 3 (4): 377-383.

[11] Su'i, M., Sumaryati, E., Prasetyo, R. and Qoyim, R. (2014). Hydrolysis coconut milk into lauric acid using endogenous lipase enzyme. Jurnal R \& D Jatim Cakrawala 8 (1): 69-76.

[12] Su'i, M., Sumaryati, E., Prasetyo, R. and Eric, D. P., 2015, Anti Bacteria Activities Of Lauric Acid From Coconut Endosperm (Hydolysed Using Lipase Endogeneus), Advances in Environmental Biology, 9 (23) : 45-49.

[13] Su'i, M., Sumaryati, E. and Sucahyono DD, 2016, Utilization of Rich Lauric Acid Fraction (Hydrolysis Results from Endosperm Coconut Using Endogeneus Lipase) as a Packaging Soy Milk Milk, Agritech Journal of Agricultural Technology, Gajah Mada University Yogyakarta, 36 (2): 154159.

[14] Sipahelut, S. G., 2011, Chemical and Organoleptic Properties of Virgin Coconut Oil Fermented Using Chain Breaking Techniques, Journal of Agroforestry, 6 (1).

[15] Fuad M., F. M., 2012, Analysis of Types and Concentrations of Enzymes Against the Saveability of VCO (Virgin Coconut Oil), Journal of AGROINTEK, 6 (2): 112-117.

[16] Asy'ari, M. Dan Cahyono, B., 2006, Pre-Standardization: Production and Analysis of Virgin Coconut Oil (VCO), JSKA., 9 (3).

[17] Setyopratiwi, A., Tahir I. and Winda, 2005, Effect of Water Types on Making Coconut Oil with Salting Methods, Proceedings of the 50th DIES National Seminar FMIPA UGM, 17 September 2005: $30-35$

[18] Sutardi, Santoso U. and Anggia, 2008, Effect of Grated Coconut Warming on VCO Quality and Quality, Agricultural Engineering Journal, 22 (2): 135-142. 
